\title{
Evaluation of Fish Passage Sites in the Walla Walla River Basin, 2008
}

\section{Annual Report}

April 2007 - August 2008

\author{
Prepared by \\ Mickie A. Chamness \\ Pacific Northwest National Laboratory \\ Richland, Washington \\ Prepared for \\ U.S. Department of Energy \\ Bonneville Power Administration \\ Division of Fish and Wildlife \\ Portland, Oregon
}

Project Number 2007-396-00

Contract Number 26934 Rel. 6 



\section{Summary}

In 2008, Pacific Northwest National Laboratory evaluated the Hofer Dam fish screen and provided technical assistance at two other fish passage sites as requested by the Bonneville Power Administration, the Walla Walla Watershed Council, or the Confederated Tribes of the Umatilla Indian Reservation. Evaluation of new sites such as Hofer Dam focuses on their design, construction, operation, and maintenance to determine if they effectively provide juvenile salmonids with safe passage through irrigation diversions.

There were two requests for technical assistance in 2008. In the first, the Confederated Tribes of the Umatilla Indian Reservation requested an evaluation of the Nursery Bridge fish screens associated with the fish ladder on the east side of the Walla Walla River. One set of brushes that clean the screens was broken for an extended period. Underwater videography and water velocity measurements were used to determine there were no potential adverse effects on juvenile salmonids when the west set of screens was clean enough to pass water normally.

A second request, received from the National Marine Fisheries Service and the Walla Walla Watershed Council, asked for evaluation of water velocities through relatively new head gates above and adjacent to the Eastside Ditch fish screens on the Walla Walla River. Water moving through the head gates and not taken for irrigation is diverted to provide water for the Nursery Bridge fish ladder on the east side of the river. Elevations used in the design of the head gates were incorrect, causing excessive flow through the head gates that closely approached or exceeded the maximum swimming burst speed of juvenile salmonids.

Hofer Dam was evaluated in June 2008. PNNL researchers found that conditions at Hofer Dam will not cause impingement or entrainment of juvenile salmonids but may provide habitat for predators and lack strong sweeping flows to encourage juvenile salmonid passage downstream.

Further evaluation of velocities at the Eastside Ditch and wasteway gates should occur as changes are made to compensate for the design problems. These evaluations will help determine whether further changes are required. Hofer Dam also should be evaluated again under more normal operating conditions when the river levels are typical of those when fish are emigrating and the metal plate is not affecting flows. 



\section{Contents}

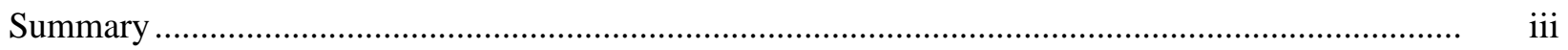

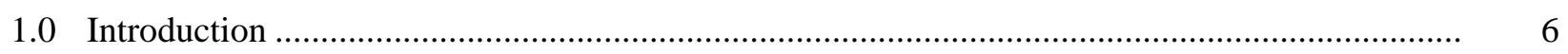

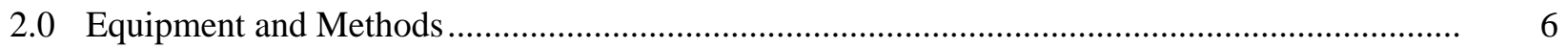

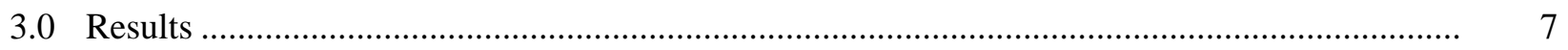

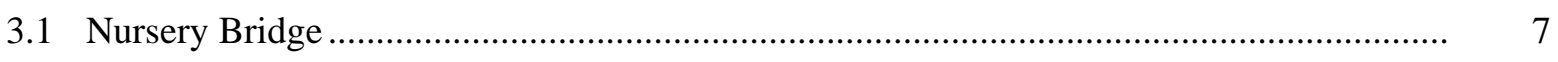

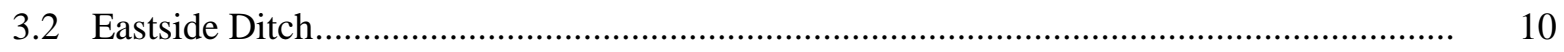

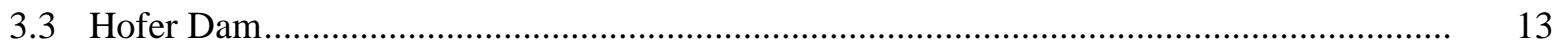

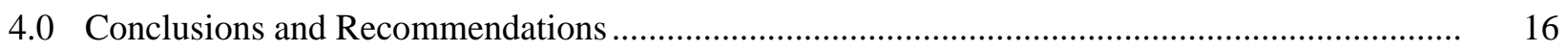

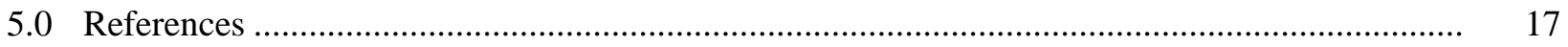

\section{Figures}

1 Location of Sites in the Walla Walla Basin Evaluated in 2008 ............................................... 8

2 Sweep and Approach Velocities in Front of Screens on the West Side of

Nursery Bridge Fishway........................................................................................................ 9

3 Sweep and Approach Velocities in Front of Screens on the East Side of Nursery Bridge Fishway..................................................................................................... 10

4 Diagram of Eastside Ditch Head Gate and Measurement Points in February 2008. ................ 11

5 Measurement Locations at Eastside Ditch Head Gate............................................................. 12

6 View Downstream Toward Hofer Dam and the Fish Screen Facility in Late July 2008............. 14

$7 \quad$ Sweep and Approach Velocities at Hofer Dam Fish Screen Facility. . ........................................ 15

8 View Upstream from Hofer Dam Toward the Fish Screen Facility in Early August 2008......... 16

\section{Table}

1 Velocity Data for Eastside Ditch Head Gate 


\subsection{Introduction}

The Northwest Power and Conservation Council (NPCC) Columbia River Basin Fish and Wildlife Program lists fish protection through effective screening of irrigation diversions as an essential element in its plan to restore declining steelhead and salmon runs (NPPC 1984, 1987, 1994, 2000). Evaluation of new sites as they become operational confirms that site design, construction, and operation allow juvenile salmonids to pass the diversion smoothly and rapidly without entrainment or impingement. Data collected at sites designed to protect juvenile salmonids passing irrigation diversions are compared to draft criteria released by the National Marine Fisheries Service (NMFS 1995).

One new site, Hofer Dam, was evaluated in 2008. The Hofer Dam fish screen facility, constructed in 2007, is located approximately $3 \mathrm{mi}$ north of Touchet on the Touchet River and immediately upstream of Hofer Dam itself. The screen facility became operational in spring 2008. On June 4, 2008, Pacific Northwest National Laboratory (PNNL) staff measured water velocities and inspected Hofer Dam using underwater videography to determine whether the site is designed, constructed, and operated to meet NMFS criteria and provide juvenile salmonids safe passage past the diversion without delay.

PNNL received two requests for technical assistance in 2008. In late January, Preston Bronson, Confederated Tribes of the Umatilla Indian Reservation (CTUIR), requested an evaluation of water velocities at the Nursery Bridge fish screens to determine whether conditions resulting from broken cleaning equipment could adversely affect juvenile salmonids emigrating in the spring. At about the same time, Larry Swenson, National Marine Fisheries Service, and Brian Wolcott, Walla Walla Watershed Council, requested water velocity measurements at the Eastside Ditch head gate and wasteway gate. The Eastside Ditch is a few hundred feet upstream from Nursery Bridge and both sites were visited on February 1. Velocities were measured at Eastside Ditch on February 29 as well.

This report provides a summary of the three evaluations conducted in 2008.

\subsection{Equipment and Methods}

Pacific Northwest National Laboratory researchers developed the methods currently used for evaluating screening facilities while conducting similar studies at fish screen facilities in the Yakima River basin (Blanton et al. 1998, 1999, 2000; Chamness et al. 2007; McMichael et al. 2004). The following is a brief discussion of the equipment and techniques used in 2008; a more detailed description of the equipment and techniques is provided in Chamness et al. (2007). Underwater videography was accomplished using a digital deep-sea camera (DeepSea Power and Light, Inc., Model MULTI-SEACAM 1050) mounted on a long pole and connected to a digital video recorder (Sony Video Walkman, Model GV-D800), which was connected in turn to a pair of video glasses (Olympus Eye-Trek, Model FMD-200). This setup allowed the operator to observe in real time what the camera encountered and provided good control over what was 
recorded digitally. This system improves the potential to identify problems, such as debris buildup or the presence of fish.

Water velocities were measured using a SonTek acoustic Doppler velocimeter (ADV, SonTek/YSI, Inc., San Diego, California). The ADV probe emits sound at $10 \mathrm{kHz}$ and measures the difference in the frequency of returning sound waves to determine the water velocity. Return times to each of three receivers extending out at an angle from the transmitter are used to calculate the three-dimensional water velocity at a point 4 in. below the probe. Water velocity data were collected at each location for $30 \mathrm{sec}$ at a rate of $2 / \mathrm{sec}$ or $4 / \mathrm{sec}$ and stored directly onto a computer. Protocols for measuring water velocities in front of a fish screen set the probe pointing down and oriented to simultaneously measure the velocity of water flowing past the screen face (sweep) and the velocity of water flowing perpendicular to the screen face (approach). Measurements in front of screens with water depths greater than 48 in. were taken at both high and low positions, corresponding to $20 \%$ and $80 \%$ of the measured forebay water depth.

Criteria for the design of Yakima Phase II fish screen facilities were developed by the National Marine Fisheries Service (NMFS 1995). These criteria provide guidelines for determining whether a site is constructed, operated, and maintained in a way that protects juvenile salmonids (McMichael et al. 2004). PNNL researchers used these criteria in analyzing the water velocity measurements at the Nursery Bridge fish screens and at Hofer Dam.

\subsection{Results}

Each of the sites evaluated in 2008 has distinct features and problems. This section presents the results of our evaluations and discusses the implications for safe passage of juvenile salmonids.

\subsection{Nursery Bridge}

The Nursery Bridge Fishway is sited on the east bank (river right) of the Walla Walla River near the town of Milton-Freewater, Oregon (Figure 1). The fish screen is at the upstream end of the fish ladder and provides auxiliary water to increase attraction flow at the fish ladder entrances. The fish screen portion of this facility consists of two horizontal-bar screens facing each other with a channel between. Each screen has its own automated cleaning brush that can be set to scrub the screen face at a predetermined time interval. When the brushes do not function properly, debris builds up on the screen face, blocking flow. If there are gaps in the debris cover, "hot spots" can develop, in which water velocities are excessively high and could impinge juvenile fish.

In late January, Preston Bronson, fish biologist with the Confederated Tribes of the Umatilla Indian Reservation, requested an evaluation of water velocities at the Nursery Bridge fishway. He was concerned that approach velocities across the screens in the fishway would not be safe for juvenile salmonids because the brush that cleans the east set of screens had been broken since late in 2007. Although Nursery Bridge Fishway is designed to provide passage for adult salmonids 
on the east side of the Walla Walla River, juvenile salmonids also use the facility as they emigrate in the spring.

On February 1, 2008, when we evaluated Nursery Bridge, stream discharge was approximately $129 \mathrm{cfs}$ at Pepper Bridge, about $10 \mathrm{mi}$ downstream of Nursery Bridge. The facility was operating under normal settings for the time of year and river levels. Screen condition on the west side was good. Brushes were working, and no debris was in front of or on the screens. Screen condition on the east side was not as good.

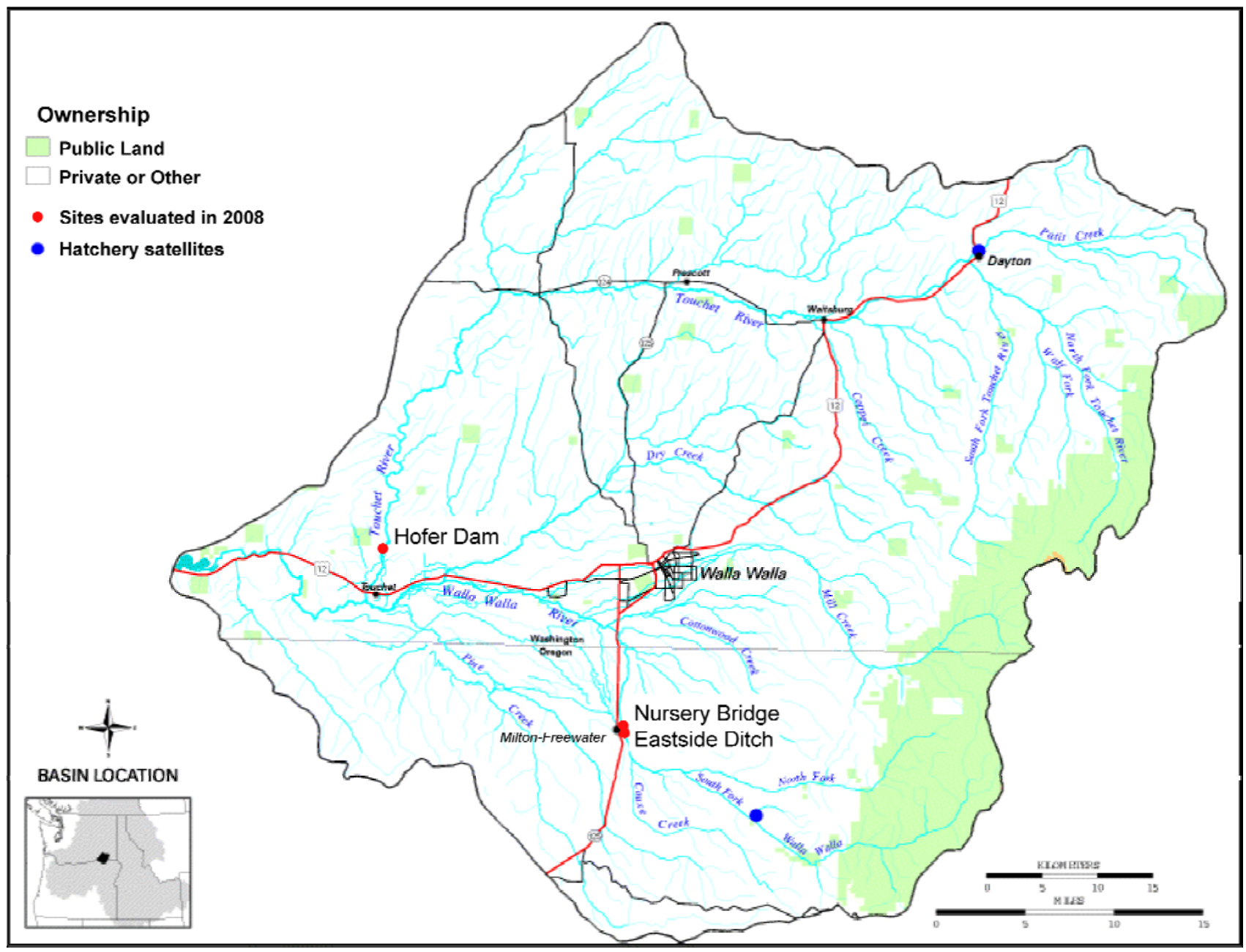

Figure 1. Location of Sites in the Walla Walla Basin Evaluated in 2008

Sticks were building up at the downstream end of the screens, and debris almost completely covered the screen faces from the middle of screen 1 (most upstream screen) down to the downstream end of screen 3; the upstream half of screen 1 was mostly clear. Hudson Bay Irrigation District staff were manually cleaning the screens with a brush at least once a day and had cleaned the screens earlier in the day on February 1.

There are three screen panels on each side of the fishway, and three measurements were made in front of each screen panel at $20 \%$ and $80 \%$ of the water depth. The Sontek ADV 3D probe was 
set to measure sweep and approach water velocities 3 in. in front of the screen face. Water velocities were measured also in the middle of the passage in front of the viewing window. The brush frame on the east side, sans brush, sat against the screen face just past the middle of the downstream screen (screen 3) panel. We measured velocities a short distance in front of the brush frame and about 8 in. behind it for the second and third measurements at screen 3 . Both measurements, but particularly the measurement downstream of the brush frame, may have been affected by flow perturbations caused by the brush frame.

Only one approach velocity at $20 \%$ water depth on the west side screen exceeded the National Marine Fisheries Service approach criterion of $0.4 \mathrm{fps}$ for safe juvenile salmon passage (Figure 2). Nothing unusual was seen at this location with the underwater camera, although sweep at the same depth showed a sharp increase at this point. The excessive values in both approach and sweep velocities probably are caused by water hitting that area as it enters the fishway through the tunnel at an angle. No hot spots were noted on the east-side screens (Figure 3). Water velocities of approximately $3.5 \mathrm{fps}$ were measured at both high and low positions in front of the viewing window.

Nursery Bridge west side screens - 2/1/08

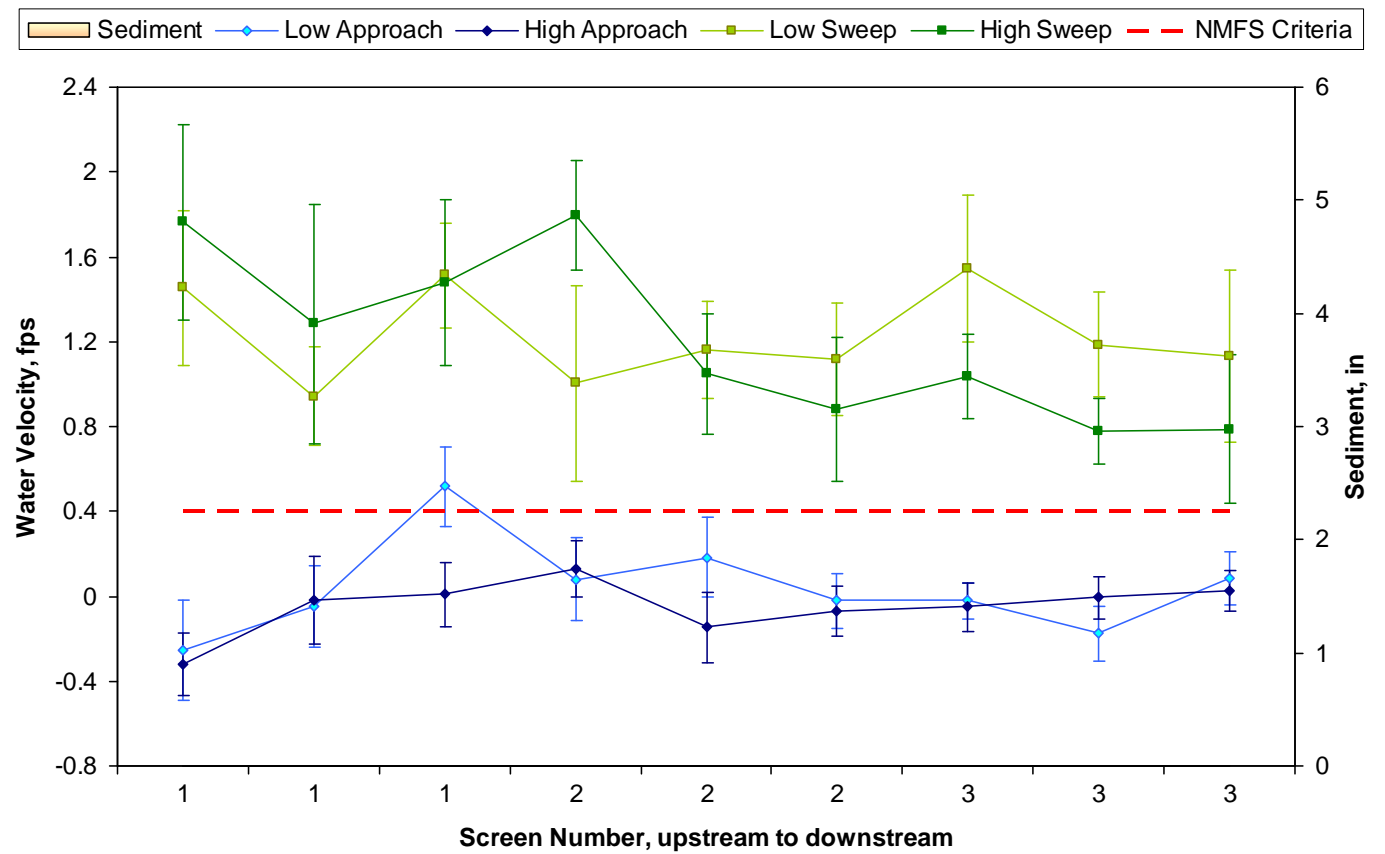

Figure 2. Sweep and Approach Velocities in Front of Screens on the West Side of Nursery Bridge Fishway. Error bars represent turbulence. 
Nursery Bridge east side screens - 2/1/08

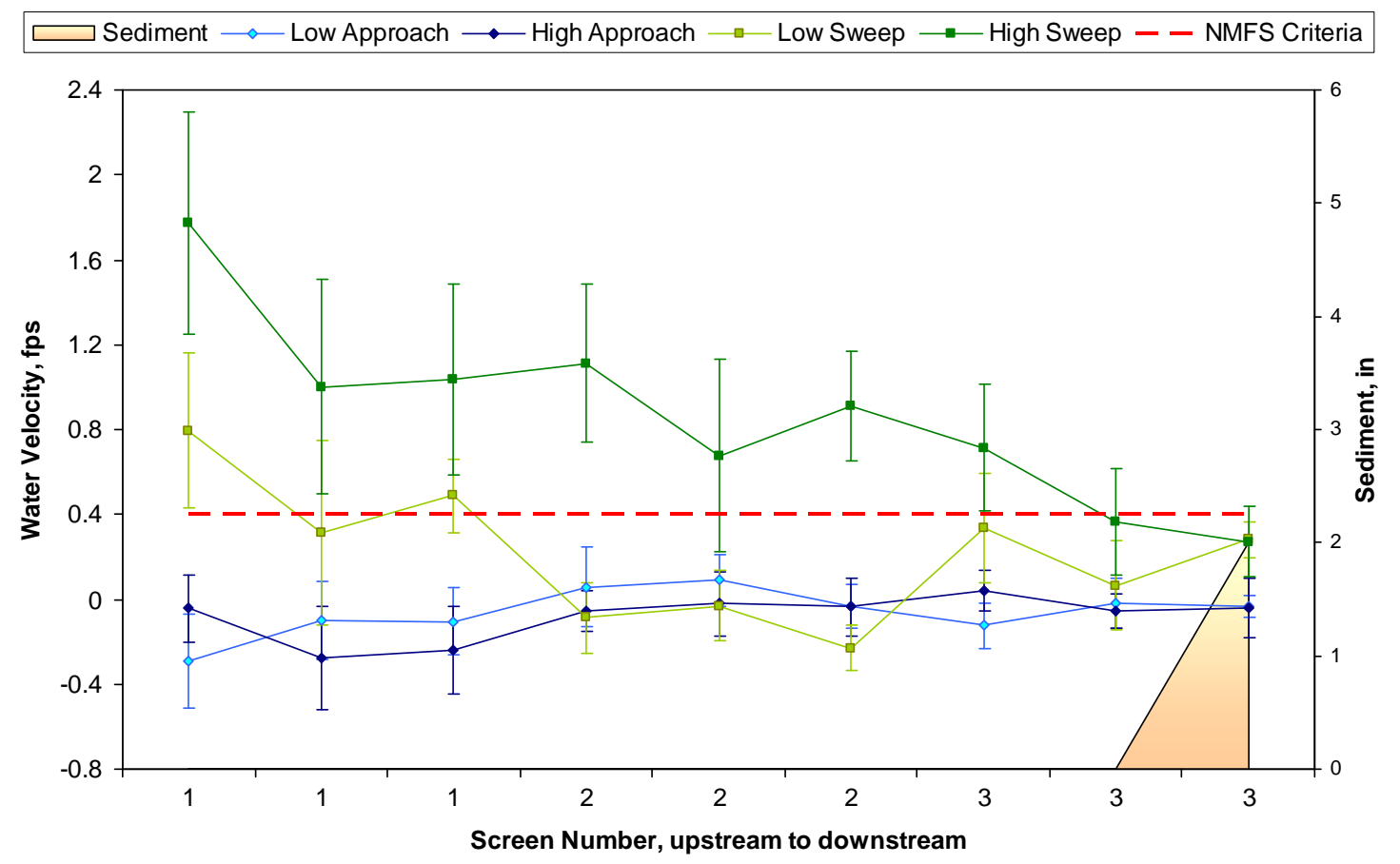

Figure 3. Sweep and Approach Velocities in Front of Screens on the East Side of Nursery Bridge Fishway. Error bars represent turbulence.

\subsection{Eastside Ditch}

The Eastside Ditch diversion is located approximately $500 \mathrm{ft}$ upstream of Nursery Bridge (Figure 1). Water is diverted by a rock weir through the Eastside Ditch head gate and down a short canal to the Eastside Ditch fish screens and irrigation ditch. Excess water not needed by the irrigation district flows through the wasteway gate back toward the river. Just below the junction of the wasteway and river and on the same side of the river is the trash rack at the entrance to the upstream end of the Nursery Bridge fish ladder. Much of the water moving through Nursery Bridge fishway passes through the Eastside Ditch head gate and wasteway gate.

In 2007, a 12-in.-wide concrete wall was placed across the entrance to the Eastside Ditch with a 78-in.-wide undershot head gate to control flow to the Eastside Ditch. The wasteway gate was installed at the same time. Subsequently, the Walla Walla Watershed Council found that the concrete floors of both gates are too high due to an erroneous elevation measurement during the site's design phase. The rock weir that diverts water through the head gate also is designed too high.

In late January 2008, Larry Swenson, National Marine Fisheries Service, and Brian Wolcott, Walla Walla Watershed Council, requested PNNL to measure velocities and water elevations at both the head gate and wasteway gate at Eastside Ditch. Mr. Swenson was concerned that the flow rates through and just past the recently installed head gate and wasteway gate might be too high for juvenile fish passage. In particular, he was concerned about the formation of a hydraulic jump just downstream of the edge of the concrete head gate floor, about $3 \mathrm{ft}$ behind the head gate. 
On February 1, PNNL staff attempted to measure the water velocity through and just past the head gate with the ADV probe and measure the water elevation using a transit. Because of snow and ice on the banks of the ditch and the relatively fast flow through the ditch, we made both transit and water velocity measurements from the head gate wall rather than by climbing down into the ditch. Measurements were made along a line through the middle of the head gate opening to minimize effects from the opening walls. River flow at Pepper Bridge monitoring station, approximately $10 \mathrm{mi}$ downstream from the site, was $129 \mathrm{cfs}$.

Differences in water elevation were measured using a Leica NA730 automatic level, sighting from 3 different locations to provide a range of values for points 1, 2, and 3 in Figure 4. These data were provided to Mr. Swenson.

Velocity measurements were attempted at $60 \%$ of the water depth at the same locations using the ADV probe. The probe was set as if measuring in front of a screen, with the probe pointing down and oriented to measure velocity in three dimensions $4 \mathrm{in}$. below the transponder. In this configuration, velocity was measured easily at position 1 above the head gate (Figure 4). At positions 2 and 3, however, turbulence created air bubbles around the probe that affected measurements at $60 \%$ of the total water depth. The middle photo in Figure 5 gives an indication of the amount of air bubbles surrounding the probe. At position 2, velocity measurements were improved by moving the probe closer to the bottom to minimize the air bubbles. No data could be collected at position 3 on February 1 because of the turbulence around the probe.

Schematic section through gate opening

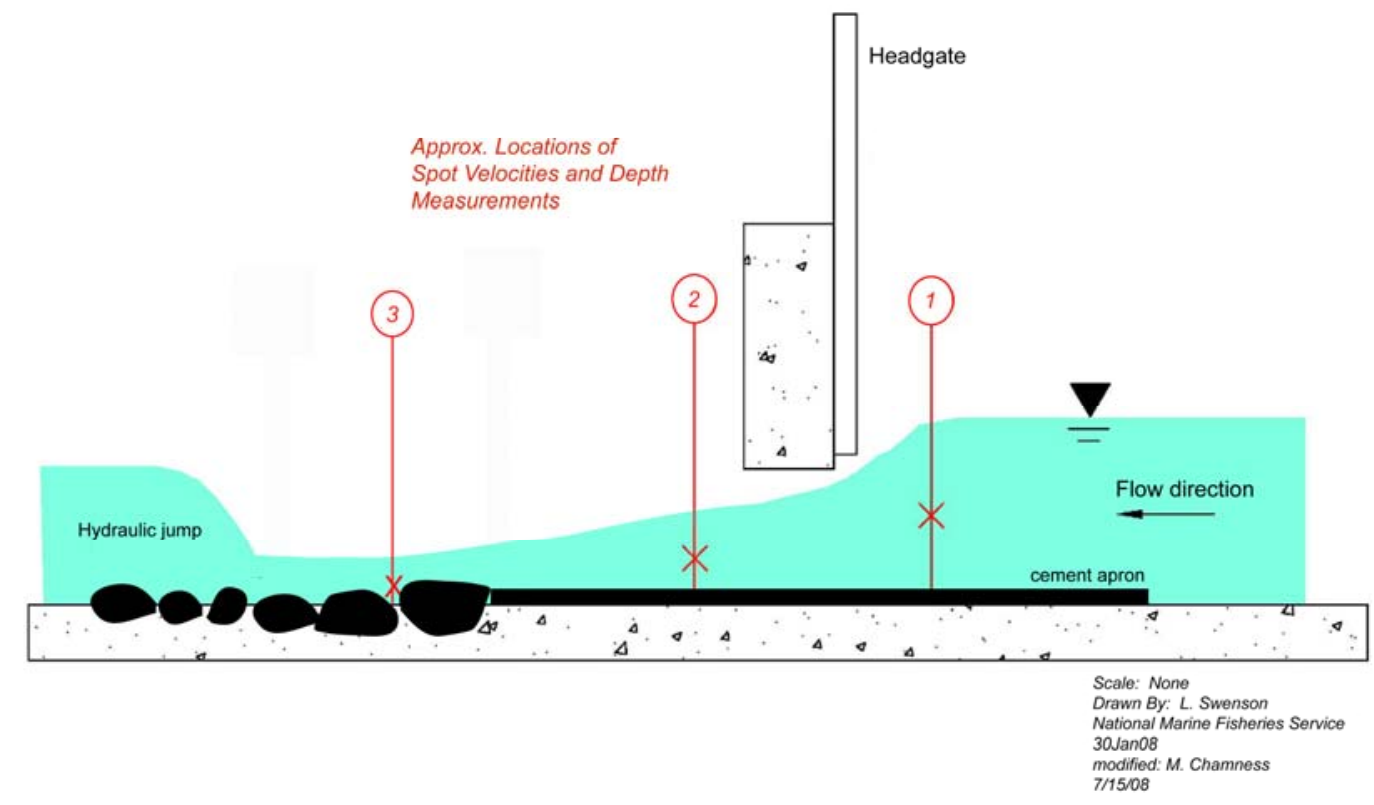

Figure 4. Diagram of Eastside Ditch Head Gate and Measurement Points in February 2008 (not to scale) 

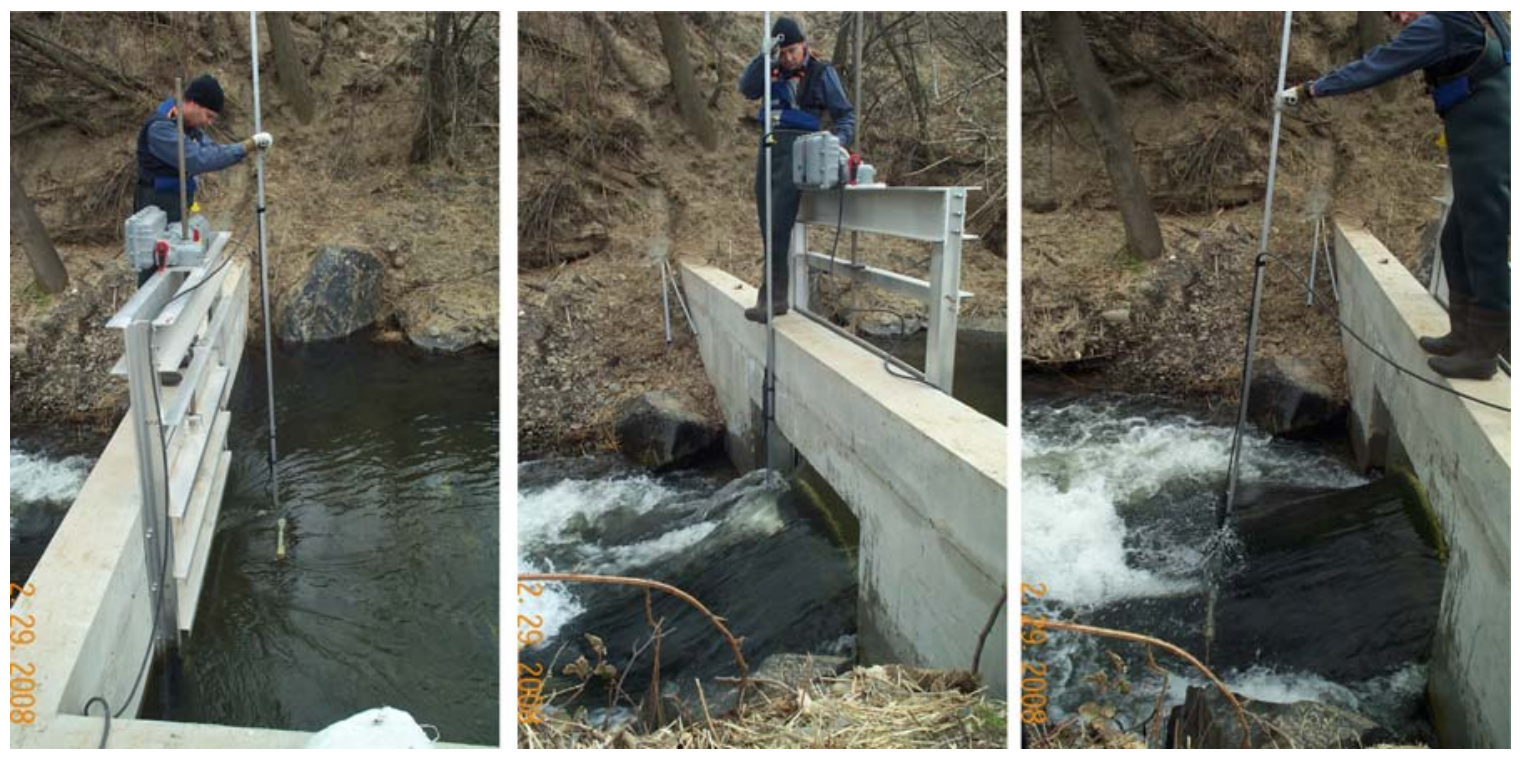

Figure 5. Measurement Locations at Eastside Ditch Head Gate. Upstream is to the right.

PNNL staff returned on February 29 to measure water velocities with the ADV probe oriented so that the transponder pointed to the side. This configuration is different from the protocol typically used for measuring velocities at screens but allowed velocity measurements to be made at the same depth as the probe (rather than $4 \mathrm{in}$. below the probe), thus reducing some of the air bubble entrainment. Data were collected at all three points shown in Figure 4, although we had to make several attempts around large rocks at measuring point 3 (Figure 5). The distance from the head gate to location 3 is about $3 \mathrm{ft}$. River flow at Pepper Bridge monitoring station, approximately $10 \mathrm{mi}$ downstream from the site, was $241 \mathrm{cfs}$, almost double the flow on February 1.

The ADV probe measures water velocities in three dimensions - two horizontal and one vertical. At screen sites, the two horizontal components measured perpendicular and parallel to the screen face are most important for fish safety near the screens. However, the maximum total water velocity through the gates and downstream is of primary interest at Eastside Ditch rather than flow in any one dimension. Consequently, these velocity data are given as the average of the individual velocity magnitudes over the 30-sec sampling time rather than all three dimensions individually. This more accurately represents the full velocity of the water at the points measured. Table 1 gives the average of the individual velocity magnitudes measured at each point for both dates, as well as the root-mean-square value as an indication of turbulence.

Table 1. Velocity Data for Eastside Ditch Head Gate

\begin{tabular}{ccccccc}
\hline \begin{tabular}{c} 
Measurement $\begin{array}{c}\text { Foint (see } \\
\text { Figure 4) }\end{array}$ \\
\cline { 2 - 7 }
\end{tabular} & $\begin{array}{c}\text { Water } \\
\text { Depth, in. }\end{array}$ & $\begin{array}{c}\text { Avg Vmag, } \\
\text { fps }\end{array}$ & $\begin{array}{c}\text { RMS } \\
\text { [Vmag], fps }\end{array}$ & $\begin{array}{c}\text { Water } \\
\text { Depth, in. }\end{array}$ & $\begin{array}{c}\text { Avg Vmag, } \\
\text { fps }\end{array}$ & $\begin{array}{c}\text { RMS } \\
\text { [Vmag], fps }\end{array}$ \\
\hline 1 & 20 & 2.40 & 0.14 & 24 & 3.41 & 0.15 \\
2 & 14 & 5.72 & 0.34 & 19 & 7.05 & 0.18 \\
3 & 16 & -- & -- & 15 & 7.34 & 1.43 \\
\hline
\end{tabular}


On February 29, velocities at the wasteway gate also were measured. This gate has two parts - a large 7.15-ft-wide section, normally closed to back up water for the irrigation canal, and a small opening, $2.5 \mathrm{ft}$ wide, to allow fish passage back to the river. In February, water was blocked from the fish screens by removable wood panels, forcing all water that entered the head gate to pass back to the river through the wasteway gate.

Mr. Swenson was concerned with flows through the wasteway gate when the large gate is closed and all water is forced through the smaller opening. PNNL's measurements at the wasteway gate do not resolve the concerns for high velocities because the large opening in the control gate was fully open and the screens were not taking water. Nonetheless, velocities were measured in the middle of the upstream side of each opening. Again, velocities given are the average of the individual velocity magnitude values over the 30 -sec sampling time to best represent the full velocity of the water. In front of the large opening, average Vmag was $5.4 \mathrm{fps}$ (RMS [Vmag] $0.39 \mathrm{fps}$ ). In front of the small opening and above the metal plate extending up from the bottom, average Vmag was $3.1 \mathrm{fps}$ (RMS [Vmag] $0.7 \mathrm{fps}$ ).

Oregon Department of Fish and Wildlife staff feels that water velocities above 8 fps would prevent adult salmonids from passing through the head gates. Velocities through and just past the Eastside Ditch head gate approach that velocity when river flows are relatively high.

Modifications are under way to change the rock weir diversion and add additional weirs between the head gate and the wasteway gate to decrease the flows through that portion of the ditch. It is anticipated that PNNL staff will be requested to measure velocities again to determine their potential effect on juvenile salmonid passage once those changes are made.

\subsection{Hofer Dam}

Hofer Dam was constructed in 2007 but was not operational until spring 2008. PNNL researchers evaluated this new fish screen on June 4, 2008. On that day, Touchet River flow at Cummins Bridge less than $2 \mathrm{mi}$ from the site was $377 \mathrm{cfs}$, which is typical of flows when juvenile fish are emigrating but higher than flows during the irrigation season.

The site has four vertical traveling screens, each 96 in. tall and 60 in. wide, with a minimum net total slot open area of 27\%. Although the Washington Department of Fish and Wildlife (WDFW) did not design or construct the facility, it has an agreement to maintain the facility. The WDFW determined that only two screens need to run at a time and asked the irrigation district to alternate monthly between running the upstream and downstream pairs. During our evaluation, the upstream two screens were turned off and the downstream two screens were operating. There is no constructed bypass at this site; water flows past the facility and through the fish ladder (Figure 6).

A trash rack extends in front of all four screens. During the evaluation, a metal plate in front of the trash rack extended from the water surface to the forebay bottom in front of the downstream screen in an effort to reduce the amount of mud accumulating in front of the screen. The metal plate was not effective and has since been removed. PNNL staff observed the underwater condition of the facility using underwater videography. Sediment had accumulated along the base of the trash rack and was more than $1 \mathrm{ft}$ deep in places. The entire bottom seal of 
screen 1 and the upstream end of screen 2 were covered by sediment. At the downstream end of screen 4, sticks, leaves, and some mud had accumulated in front of the bottom seal.

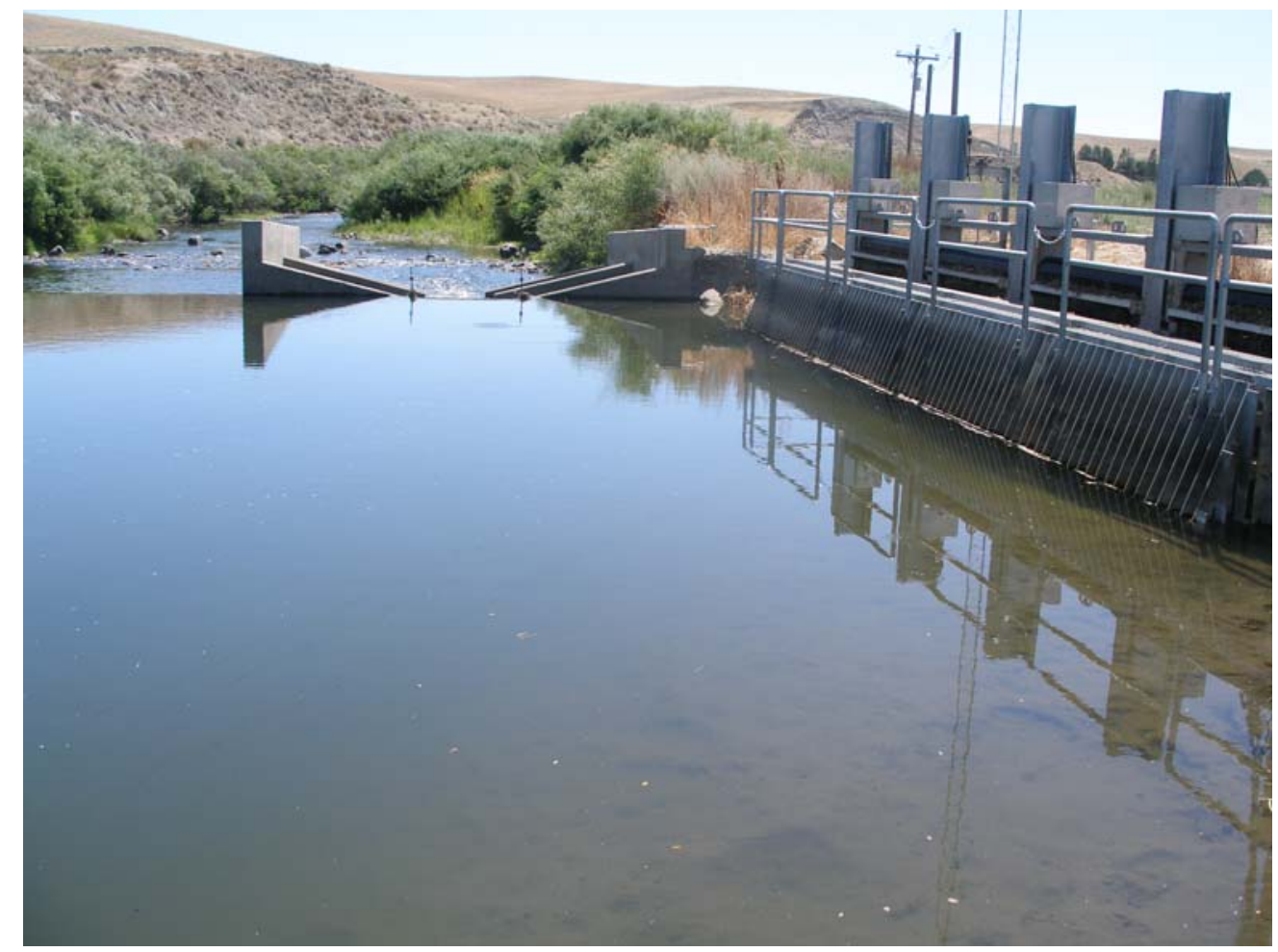

Figure 6. View Downstream Toward Hofer Dam and the Fish Screen Facility in Late July 2008

Screen condition was good for screens 3 and 4, and side seal condition was good for all screens. Screens 1 and 2 had not been run for several weeks and were not running during our evaluation. Horizontal brushes have been attached to each screen frame to knock debris back into the forebay instead of letting the debris roll over into the aftbay. The irrigation canal is piped to a pump station less than $0.5 \mathrm{mi}$ away, and debris could become a problem in the pipe and pump if allowed to fall into the aftbay.

Using the protocol for measuring water velocities in front of fish screens described in Section 2, PNNL made velocity measurements at $20 \%$ and $80 \%$ of the water depth in the forebay at one location in front of screens 1 and 2 and at three locations in front of each of screens 3 and 4. Algae and debris that accumulated on these two screens blocked flow through screens 1 and 2 (Figure 7). A back eddy was visible at the downstream end of the facility.

The NMFS criterion concerning sweep states that sweep velocity should be greater than approach velocities. Sweeping flow was erratic; water was flowing upstream in front of screens 1 and 2 and most of 3 and 4 at $20 \%$ of the water depth, while at $80 \%$ of the water depth the water flowed upstream abruptly at the downstream end of screen 3 (Figure 7). Nevertheless, Hofer Dam sweep velocities marginally met the criterion. Approach velocities were not as erratic, increasing downstream until screen 4 and then decreasing. Only one measurement exceeded the NMFS criterion of 0.4 fps for approach velocities. Water moved away from screens 1 and 2 as 
would be expected because the algae blocks flow through the screens. Overall, erratic flows may have been caused by the back eddy, by the effect of the metal plate on water flow, or by some combination of the two. Design flows for this site are unknown, and it is possible that relatively high river levels also contributed to flow perturbations.

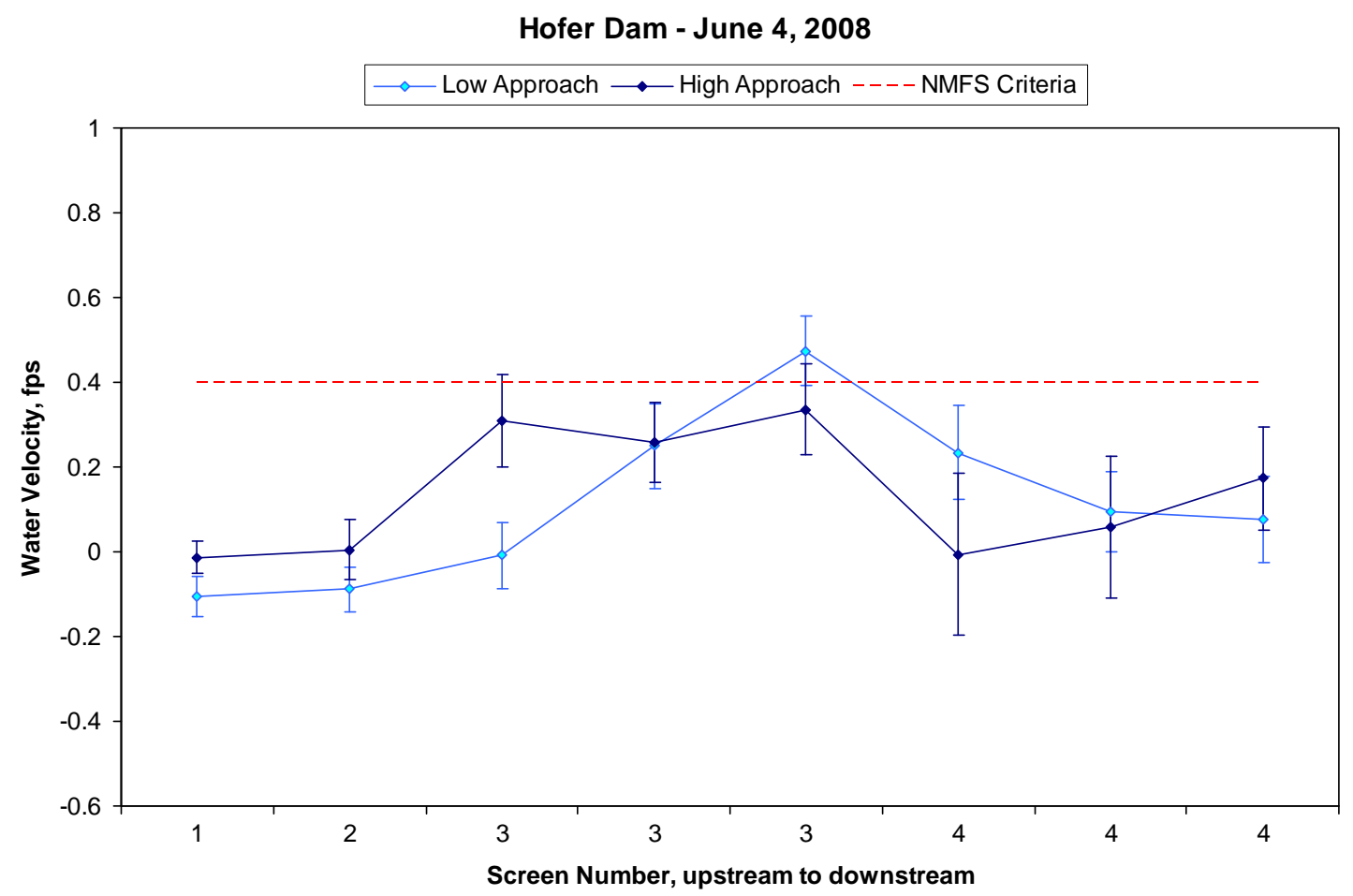

Figure 7. Sweep and Approach Velocities at Hofer Dam Fish Screen Facility. Error bars represent turbulence.

The back eddy is probably due at least in part to the placement of the screen site relative to the main current of the river and the western end of the dam. The site is set in a small embayment just upstream of Hofer Dam (Figure 8), and the main flow of the river toward the fish ladder is too far away to provide good sweeping flow past the screens. The downstream end of the screen site ends in a small pocket of shoreline at the western end of the dam, which may contribute to the development of a back eddy. The metal plate on the trash rack in front of the downstream screen also affected flow and may have caused or contributed to the erratic flows observed. 


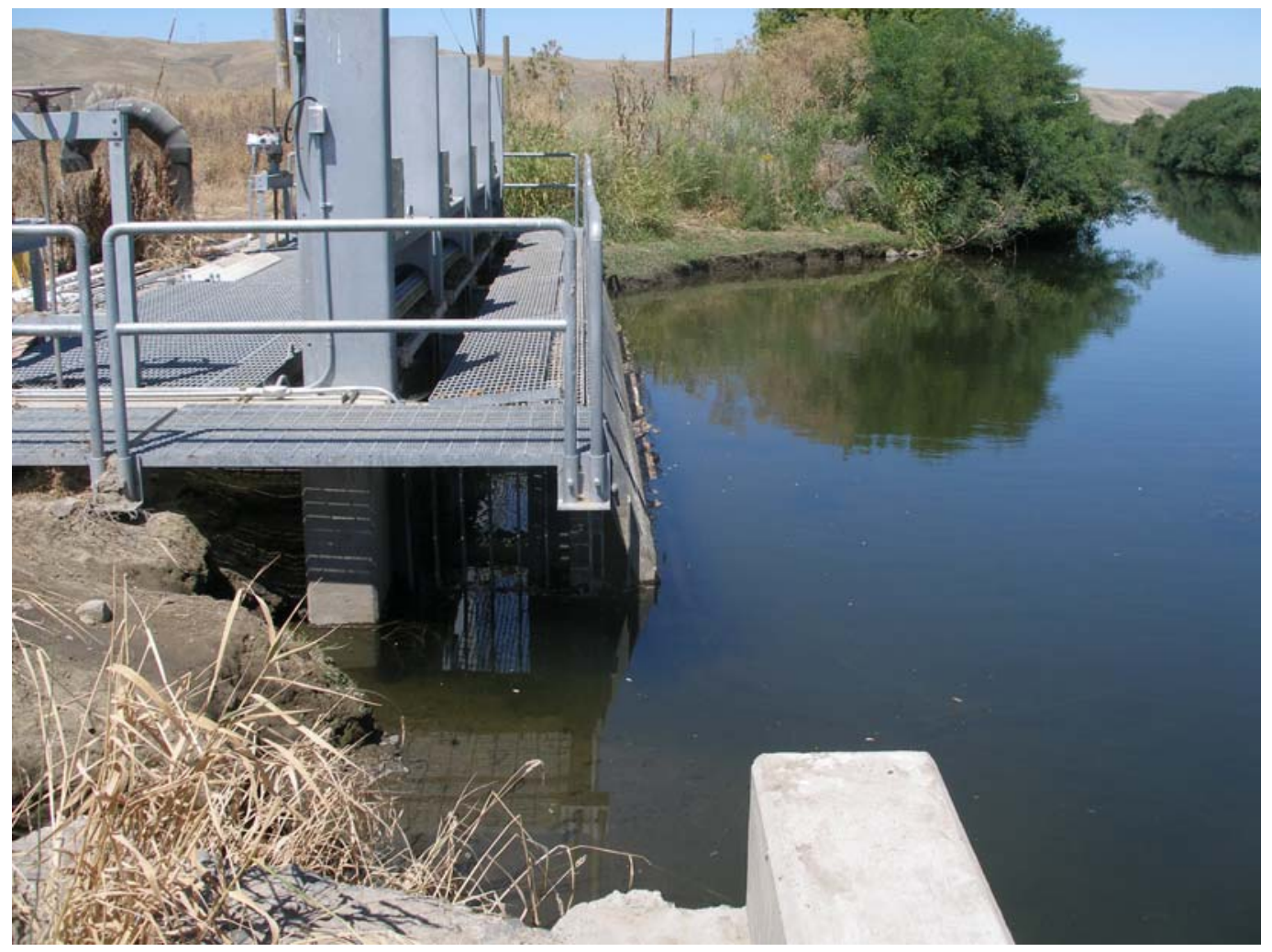

Figure 8 View Upstream from Hofer Dam Toward the Fish Screen Facility in Early August 2008. Note the main thalweg is off the right side of the photo.

\subsection{Conclusions and Recommendations}

Evaluation of Nursery Bridge fish screens did not indicate immediate problems caused by the inability to keep the east screens free of debris. Approach values were above the criterion of 0.4 fps in the same area they have been high in the past, where the main force of the current hits the screen after exiting the tunnel under the bridge.

Data collected at Eastside Ditch indicate water velocities through and downstream from the head gate are sufficiently high during early spring flow conditions (2.4 to 7.34 fps) to pose an obstacle to juvenile fish passage. Velocities through the wasteway gate are not as high as those through the head gate during spring flow conditions. However, velocities have not been measured under later spring river conditions when the larger opening is closed and all water is moving through the smaller opening and the irrigation

canal is withdrawing water. Erroneous elevation measurements leading to design problems have been identified, and a number of temporary and permanent solutions are being considered by the Walla Walla Watershed Council, NMFS, CTUIR, and Oregon Department of Fish and Wildlife. Additional velocity measurements should be made as changes to the site occur and when the irrigation district is diverting water to the canal. 
The Hofer Dam screen facility is in a small embayment on the west shore of the Touchet River where flow is generally slower and back eddies may develop at times. Approach velocities at Hofer Dam screen facility met the NMFS criterion in June, but sweep flows did not. Sweep velocities were erratic and flowed upstream in places, leading to debris and mud buildup. Slow sweep velocities could potentially cause juvenile fish to delay their emigration. These conditions may also provide habitat for predators such as the smallmouth bass (Micropterus dolomieui) seen at the site in 2007. Part of the problem may be due to placement of the facility in a back eddy to the side of the dam, but part may be due also to the metal plate in front of the downstream screen. The site should be evaluated again under more normal operating conditions when the river levels are typical of those when fish are emigrating and the metal plate is not affecting flows.

\subsection{References}

Blanton SL, DA Neitzel, and CS Abernethy. 1998. Washington Phase II Fish Diversion Screen Evaluations in the Yakima River Basin, 1997. DOE/BP-00029-5, prepared by Pacific Northwest National Laboratory for the Division of Fish and Wildlife, Bonneville Power Administration, Portland, Oregon.

Blanton SL, GA McMichael, and DA Neitzel. 1999. Washington Phase II Fish Diversion Screen Evaluations in the Yakima River Basin, 1998. DOE/BP-62611-15, prepared by Pacific Northwest National Laboratory for the Division of Fish and Wildlife, Bonneville Power Administration, Portland, Oregon.

Blanton SL, GA McMichael, and DA Neitzel. 2000. Washington Phase II Fish Diversion Screen Evaluations in the Yakima River Basin, 1999. DOE/BP-00000652-4, prepared by Pacific Northwest National Laboratory for the Division of Fish and Wildlife, Bonneville Power Administration, Portland, Oregon.

Chamness MA, CS Abernethy, and C Tunnicliffe. 2007. Walla Walla River Basin Fish Screens Evaluations, 2006 Annual Report. DOE/BP-00000652-36, prepared by Pacific Northwest National Laboratory for the Division of Fish and Wildlife, Bonneville Power Administration, Portland, Oregon.

McMichael GA, JA Vucelick, CS Abernethy, and DA Neitzel. 2004. "Comparing Fish Screen Performance to Physical Design Criteria.” Fisheries 29(7):10-16.

NMFS (National Marine Fisheries Service). 1995. Draft Juvenile Fish Screen Criteria. National Marine Fisheries Service, Environmental \& Technical Services Division, Portland, Oregon.

NPPC (Northwest Power Planning Council). 1984. Fish and Wildlife Program: Measure 704(d). Northwest Power Planning Council, Portland, Oregon.

NPPC (Northwest Power Planning Council). 1987. Fish and Wildlife Program: 1403.4. Northwest Power Planning Council, Portland, Oregon. 
NPPC (Northwest Power Planning Council). 1994. Fish and Wildlife Program: Measure 7.10. Northwest Power Planning Council, Portland, Oregon.

NPPC (Northwest Power Planning Council). 2000. Fish and Wildlife Program. Northwest Power Planning Council, Portland, Oregon. 